\title{
EASTERNMOST RECORD OF THE LANCET FISH, NOTOSCOPELUS KROYERI (ACTINOPTERYGII: MYCTOPHIFORMES: MYCTOPHIDAE), IN THE MEDITERRANEAN SEA
}

\author{
${\text { Cetin } \text { KESKIN }^{1 *} \text { and Lütfiye ERYILMAZ }}^{2}$ \\ ${ }^{1}$ Department of Marine Biology, Fisheries Faculty, Istanbul University, \\ ${ }^{2}$ Department of Biology, Science Faculty, Istanbul University Istanbul, Turkey
}

Keskin C., Eryilmaz L. 2010. Easternmost record of the lancet fish, Notoscopelus kroyeri (Actinopterygii: Myctophiformes: Myctophidae), in the Mediterranean Sea. Acta Ichthyol. Piscat. 40 (1): 79-81.

Abstract. One specimen of lancet fish, Notoscopelus kroyeri (Malm, 1861), was collected in March 2007 by commercial bottom trawl in the Aegean Sea. This record consists the easternmost record of lancet fish in the Mediterranean Sea. Morphometric and meristic characteristics of this species are given.

Keywords: Notoscopelus kroyeri, lancet fish, Myctophidae, first record, deep-sea fish, easternmost Mediterranean Sea

The Lancet fish, Notoscopelus kroyeri (Malm, 1861), is N. elongatus (Costa, 1844); N. kroyeri (Malm, 1861); and a species of the family Myctophidae. This family includes $N$. resplendens (Richardson, 1845). N. kroyeri is a about 32 genera with at least 240 species (Nelson 2006). Five mesopelagic species found in depths ranging from $325 \mathrm{~m}$ species are recognized in the genus Notoscopelus in the North- to deeper than $1000 \mathrm{~m}$. During the day, it is nyceastern Atlantic and the Mediterranean (Hulley 1984): N. boli- toepipelagic at surface and down to $125 \mathrm{~m}$ (maximum ni Nafpaktitis, 1975; N. caudispinosus (Johnson, 1863); abundance at 0-40 m) (Hulley 1984).

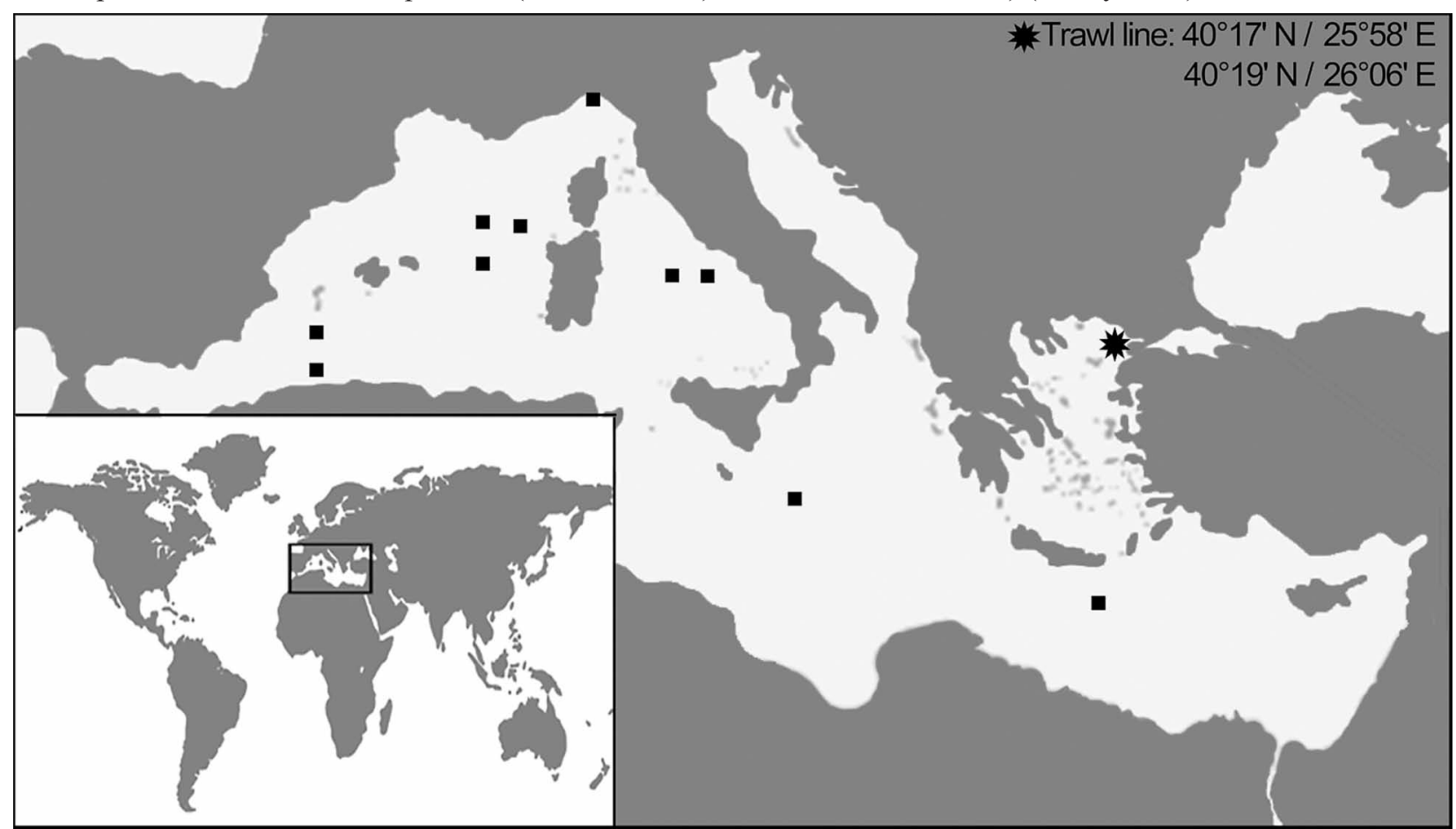

Fig. 1. Museum records of Notoscopelus kroyeri in the Mediterranean Sea ( $\square$ ) by Froese and Pauly (2009), and sampling location in the present study (**)

\footnotetext{
${ }^{*}$ Correspondence: Dr. Cetin Keskin, İstanbul Üniversitesi, Su Ürünleri Fakültesi, Ordu C. 200, Laleli, 34470 İstanbul, Turkey, phone: +90 2124555700 , fax: +90 21251403 79, e-mail: seahorse@istanbul.edu.tr.
} 
$N$. kroyeri has been reported so far from western North ern sector between $37^{\circ} \mathrm{N}$ and the Arctic Circle and in the Atlantic (Nafpaktitis et al. 1977) and the Flemish Cap (an western sector between $40^{\circ} \mathrm{N}$ and $60^{\circ} \mathrm{N}$, this species is area of shallow waters in the North Atlantic Ocean centred given such records based on museum collections also in roughly at $47^{\circ} \mathrm{N}, 45^{\circ} \mathrm{W}$ or about 350 miles $(560 \mathrm{~km}$ ) east of the western Mediterranean Sea (e.g., Malta, West Italy, St. John's, Newfoundland and Labrador) (Bañón et al. 2001). Southern Crete) (Froese and Pauly 2009) (Fig. 1). N. kroyAlthough Hulley (1984) reported that distribution area of eri was included in the list of Mediterranean fish biodiverN. kroyeri is restricted to the northern Atlantic, in the east- sity by Quignard and Tomasini (2000) who did not indi-

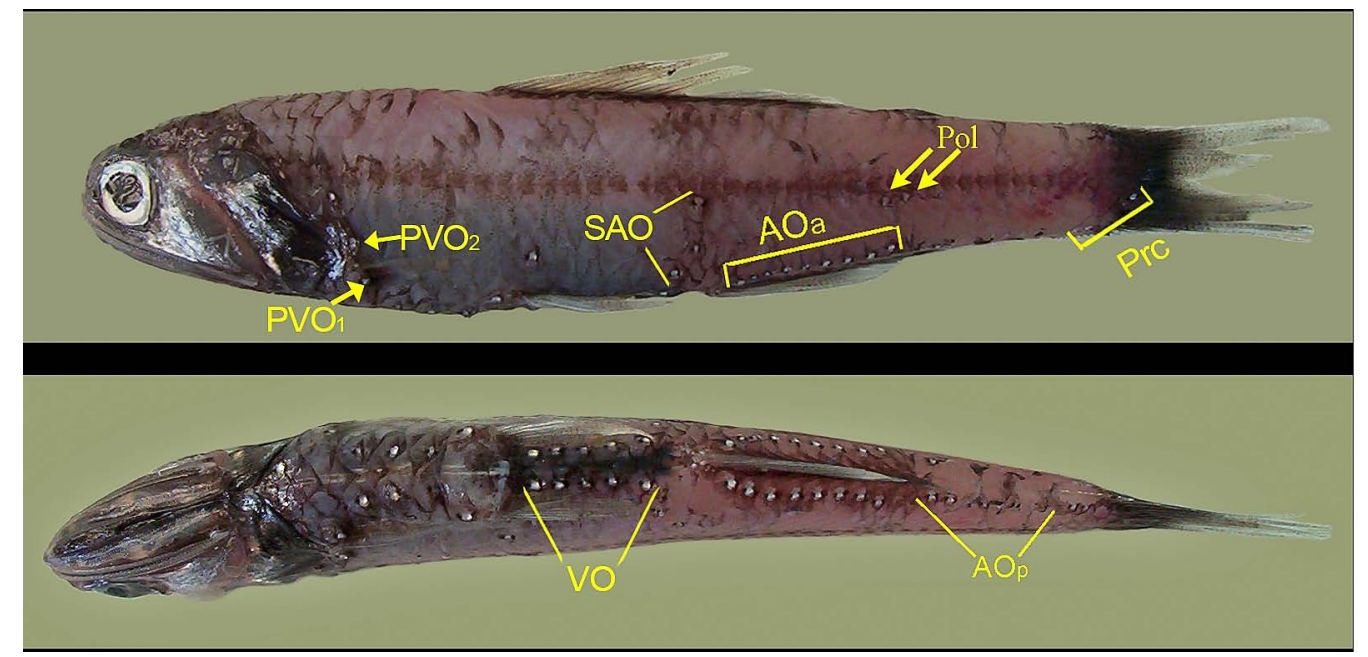

Fig. 2. Specimen of Notoscopelus kroyeri (IUSHM 37920-255; TL: $140 \mathrm{~mm}$ ) caught in the Mediterranean Sea

Comparisons of morphometric and meristic characteristics of Notoscopelus kroyeri

Table 1 in the present study and other studies (measurements in $\mathrm{mm}$ )

\begin{tabular}{|c|c|c|c|c|}
\hline Characteristics & Present study & Nafpaktitis et al. 1977 & Hulley 1984 & Bañón et al. 2001 \\
\hline Total length & 140 & $23-133$ & 143 & $84-132$ \\
\hline Standard length (SL) & 117 & & & \\
\hline Fork length & 125 & & & \\
\hline Head length (HL) & 31 & & & \\
\hline Upper jaw length & 23.2 & & & \\
\hline Lower jaw length & 23.1 & & & \\
\hline Snout length & 4.6 & & & \\
\hline Eye diameter & 8 & & & \\
\hline Predorsal length & 43.8 & & & \\
\hline Dorsal fin base length & 30 & & & \\
\hline Preanal length & 70 & & & \\
\hline Anal fin base length & 21.1 & & & \\
\hline Head length in SL & 3.8 & $3.5-3.8$ & & \\
\hline Upper jaw length in SL & 5.0 & $4.5-5.2$ & & \\
\hline Eye diameter in SL & 14.6 & $12.5-15$ & & \\
\hline Snout length in HL & 6.7 & & & \\
\hline Eye diameter in HL & 3.9 & $3.8-4$ & & \\
\hline Upper jaw length in HL & 1.3 & $1.3-1.4$ & & \\
\hline Eye diameter in upper jaw length & 2.9 & $2.8-3$ & & \\
\hline Dorsal fin rays & 22 & $21-22$ & $22(21)$ & $22(21)$ \\
\hline Anal fin rays & 18 & $19(18-20)$ & $19(18-20)$ & $19(18-20)$ \\
\hline Pectoral fin rays & 13 & 13 & $12-13$ & $12-13$ \\
\hline Ventral fin rays (left/right) & $7 / 9$ & & & \\
\hline Gill rakers & $\begin{array}{l}8+1+17 \\
\text { total } 26\end{array}$ & $\begin{array}{c}(8-9)+1+(17-19)(20) \\
\text { total } 26-29(30)\end{array}$ & $\begin{array}{l}8+1+17(18) \\
\text { total } 26(27)\end{array}$ & $\begin{array}{c}(8-9)+1+(17-18) \\
\text { total } 26-28\end{array}$ \\
\hline $\mathrm{AO}(\mathrm{AOa}+\mathrm{AOp})$ & $\begin{array}{l}9+7 \\
\text { total } 16\end{array}$ & $\begin{array}{l}9(8-10)+7(6-8) \\
\text { total } 16(15-17)\end{array}$ & $\begin{array}{c}9(10)+7(6-8) \\
\text { total } 16(15-18)\end{array}$ & $\begin{array}{l}9(8-10)+7(6-8) \\
\text { total } 16(15-18)\end{array}$ \\
\hline Lateral-line organs & 42 & $42-43$ & & \\
\hline
\end{tabular}


cate where it was found in this sea nor did they give its morphomeristic characters. Considering to the above-mentioned knowledge on the distribution areas of N. kroyeri, this paper represents the easternmost record of this species in the Mediterranean Sea.

A $140 \mathrm{~mm}$ (TL) specimen was caught between $40^{\circ} 17^{\prime} \mathrm{N}$ and $25^{\circ} 58^{\prime} \mathrm{E}$, and between $40^{\circ} 19^{\prime} \mathrm{N}$ and $26^{\circ} 06^{\prime} \mathrm{E}$ in the North Aegean Sea in March 2007 during the day by commercial bottom trawl, at depth between $475 \mathrm{~m}$ and 350 $\mathrm{m}$ (Fig. 1). The specimen was fixed and preserved in 5\% formalin solution and deposited in the Istanbul University, Science Faculty, Hydrobiology Museum, Istanbul (IUSHM 37920-255) (Fig. 2). Measurements were made with dial callipers and recorded to $0.1 \mathrm{~mm}$. The species name was attributed following Eschmeyer (1998).

Diagnostic characters of the specimen were measured following Nafpaktitis et al. (1977) and Hulley (1984). The diagnostic characters of the lancet fish in this study and in accordance with those observed in other areas are given in Table 1.

The description of the captured specimen is as follows: Head and body compressed, eyes large and lateral; mouth large, jaws extending more than one eye diameter behind posterior margin of orbit; AO series divided into AOa and AOp, the last AOa raised, AOp behind base of anal fine; two Pol, horizontally arranged at lateral line; $\mathrm{VO}$ 5; $\mathrm{SAO} 3$; $\mathrm{VO}_{5}, \mathrm{SAO}_{1}$ and $\mathrm{SAO}_{2}$ equidistant and nearly in a straight line. PVO 2, $\mathrm{PVO}_{2}$ well above level of upper end of base of pectoral fin; last Prc below level of lateral line. Origin of dorsal fin slightly in advance of ventral fin base. Origin of anal fin behind of middle of dorsal fin base. Pectoral fins short, not reaching the bases of ventral fins; ventral fins extending to anus. Adipose fin origin slightly in advance of end of anal fin base.

All counts and measurements agree with descriptions of $N$. kroyeri given by Nafpaktitis et al. (1977) and Hulley (1984). N. kroyeri can be distinguished from other Atlanto-Mediterranean co-generic species of the genus Notoscopelus (N. caudispinosus, $N$. resplendens, and $N$. elongatus) by the large number of gillrakers (26-30; see Table 1), as compared to 25 or less in these species; while from $N$. bolini, it can be separated by having 21-22 dorsal fin rays as compared to 23-26.

\section{ACKNOWLEDGEMENTS}

Thanks go to the crew of the trawl vessel PAPUÇOĞLU for obtaining specimen. The authors are indebted to Daniel Golani for the valuable comments on the manuscript, Murat Bilecenoğlu for providing helpful literature and Cem Dalyan for help during the study.

\section{REFERENCES}

Bañón Díaz R., Cerviño S., Campelos J.M. 2001. Composición, distiribución y descripción de mictófidos (Pisces, Myctophidae) encontrados en Flemish Cap (Atlántico noroeste) en verano de 1998. Boletín, Instituto Español de Oceanografía 17: 287-294.

Eschmeyer W.N. 1998. Catalog of Fishes on-line [updated July 02, 2009]. http://www.calacademy.org/research/ichthyology/ /catalog/fishcatmain.asp.

Froese R., Pauly D. Editors. 2009. FishBase. [version 06/2009] http://www.fishbase.org.

Hulley P.A. 1984. Myctophidae. Vol. I. Pp. 429-483. In: Whitehead P.J.P., Bauchot M.-L., Hureau J.-C., Nielsen J., Tortonese E. (eds.) Fishes of the North-eastern Atlantic and the Mediterranean. Paris, UNESCO.

Nafpaktitis B.G., Backus R.H., Craddock J.E., Haedrich R.L., Robison B.H., Karnella C. 1977. Fishes of the western north Atlantic, Order Iniomi (Myctophiformes). Memoir 1, Part 7, 287 pp. Sears Foundation for Marine Research, Yale University, New Haven.

Nelson J.S. 2006. Fishes of the world (4th edn.). John Wiley and Sons, New York.

Quignard J.P., Tomasini J.A. 2000. Mediterranean fish biodiversity. Biologia Marina Mediterranea 7: 1-66.

Received: 24 March 2009

Accepted: 9 September 2009

Published electronically: 25 June 2010 